Original Article (short paper)

\title{
Associated factors and profile of injuries in professional ballroom dancers in Brazil: a cross-sectional study
}

\author{
Allana Alexandre Cardoso ${ }^{1}$ (D), Nycolle Martins Reis ${ }^{2}$ (D), Melissa de Carvalho Souza Vieira ${ }^{2}$ (D), \\ Adriano Ferreti Borgatto $^{3}$ (D), Alexandra Folle ${ }^{4}$ (D), Adriana Coutinho de Azevedo Guimarães ${ }^{4}$ (D) \\ ${ }^{1}$ Universidade Federal de Santa Catarina, Centro de Desportos, Florianópolis, SC, Brasil. \\ ${ }^{2}$ Universidade do Estado de Santa Catarina, Centro de Ciências da Saúde e do Esporte, \\ Florianópolis, SC, Brasil. \\ ${ }^{3}$ Universidade Federal de Santa Catarina, Centro Tecnológico, Departamento de Informática e \\ Estatística, Florianópolis, SC, Brasil. \\ ${ }^{4}$ Universidade do Estado de Santa Catarina, Centro de Ciência da Saúde e do Esporte, Programa \\ de Pós-Graduação em Ciências do Movimento Humano do CEFID, Florianópolis, SC, Brasil.
}

\begin{abstract}
Aims: Ballroom dance consists of a modality characterized by fast and dynamic movements performed in pairs, aiming at technical and artistic excellence. Objective: To analyze the prevalence, characteristics, and factors associated with injuries in professional ballroom dancers, considering possible differences between sexes. Method: 320 professional dancers of both sexes with a mean age of $31.48 \pm 8.63$ years, who were in professional companies and/ or dance schools from five regions of Brazil. The measurement was performed through an online self-administered questionnaire about general information and injuries. Results: A high frequency of musculoskeletal injuries (80.0\%) was observed, especially osteoarticular ones $(52.4 \%)$. In women, the lower limbs were the anatomical location most reported $(31.1 \%)$ and the knee in male dancers $(28.7 \%)$. Overweight men, with more than 11 years of dance practice, who danced in companies and also performed other physical activities, were more likely to have injuries. However, women were less likely to have injuries when they were overweight and more likely when they practiced other dance modalities besides ballroom dancing. Conclusions: Approximately $64.1 \%$ of ballroom dancers suffered an injury throughout their professional careers. For men, being overweight as well as the search for complementary activities to the physical training routine for both sexes, seem to influence the occurrence of injuries. Identification of the factors associated with injuries in ballroom dancers contributes both to preventive actions and to rehabilitation processes, favoring a healthy and safe career for professionals involved in this practice.
\end{abstract}

Keywords: dancing, ballroom dance, musculoskeletal injuries, movement.

\section{Introduction}

Professional dancers have a training routine that demands artistic excellence, sensitivity to specific physical abilities and advanced techniques ${ }^{1}$. Their performance combines technical and esthetical values and professional dancers are compared to elite athletes, but the training routines may lead to physical exhaustion, reaching their limit ${ }^{2}$.

Considered as an artistic and athletic activity, the practice of dancing involves static and dynamic work from large and small muscle groups, together with adequate interaction of upper and lower limb movements as well as constant interaction with other dancers, whether on stage or in the dance room ${ }^{3}$. Amongst the dancing modalities, ballroom dancers stand out, dancing in pairs, generally, a man with a woman, involving the learning of different rhythms which vary culturally from country to country ${ }^{4}$. Each rhythm has its own posture according to the style, as also specific movements and steps. In addition, ballroom dancers are constantly exploring their balance due to the fast movements and changes in direction present in the rhythm, involving ample work with twisting, axis transfer, steps, and jumps. The women use high-heeled sandals with restricted bases and change their gravity center ${ }^{5}$. Such movements can lead to great postural instability, favoring the development of injuries ${ }^{5,6}$.

Some factors such as the body mass index, clothing (high heeled sandals), time practicing the modality, repetitive movements, sex, and age may be associated with the prevalence of injury ${ }^{6}$. In addition, inadequate technique and space, the floor surface and a lack of dancing equipment may also contribute to the occurrence of injuries ${ }^{1,7}$.

In high yield athletes, musculoskeletal injuries recur most frequently and can be understood as damage caused to the organism as a consequence of an overload on these structures $^{8,9}$. The prevalence of injury in amateur dancers 
varies from $40 \%$ to $84 \%{ }^{10}$, and epidemiological studies estimate that this percentage may reach $90 \%$ in professional dancers ${ }^{1}$. Studies point out that the lower limbs are the most affected in professional classical ballet, modern and contemporary dancers ${ }^{11}$, but there are no data available for professional ballroom dancers.

Considering the above, the authors believe it is highly relevant to the health area to carry out a study which proposes to investigate the prevalence and incidence of injuries in the ballroom dancing modality, because actions could be proposed that aim to prevent them, providing better quality for the personal and professional life of dancers, which impacts on an improvement in their performance.

Above all, this study had the objective of alerting the dancers of the possible risks involved in inadequate practices, stimulating preventative and conscious attitudes in the professional ballroom dancing context. Thus, the present study aims to analyze the prevalence, characteristics and possible factors associated with injuries in professional ballroom dancers in Brazil, considering any possible differences between the sexes. It is believed that there is a high incidence of musculoskeletal injuries mostly in the lower limbs, and female dancers would be the most affected.

\section{Material and Methods}

This was a descriptive cross-sectional design, approved by the Ethics Committee for Research with Human Beings (CEPSH) of the Santa Catarina State University (UDESC), process $n^{\circ} 1.320 .412$ on November $12^{\text {th }}$, 2016.

A total of 320 professional ballroom dancers took part in the study, with a mean age of $31.48 \pm 8.63$ years, selected using a non-probabilistic intentional sample, and $187(58.4 \%)$ being men. Since there are no regulatory organs for professional ballroom dancers in Brazil, the sample was chosen by convenience, using registers made available online by regional associations, such as the National Ballroom Dancing Association (ANDANÇAS); The Brazilian Commission for Ballroom Dancing (CBDS); The Santa Catarina Ballroom Dancing Association (ACADS) and the Rio de Janeiro Association of Professional Ballroom Dancers (APDS). It is important to highlight that, in the cadres of the Brazilian Classification of Occupations by the Ministry of Labor and Employment (CBO), for the profession of the dancer, the term "professional dancers" was adopted for this research.

Due to the non-regulation of the category "dance professionals" in Brazil, in order to ensure a better homogeneity of the sample, some inclusion criteria were adopted: professional dancers of both sexes, over 18 years of age, who had practiced and taught ballroom dancing classes for at least 6 years, and trained the modality in a sys- tematized way for a minimum of three times a week. In addition, they had to be employed by a professional ballroom dancing company or belong to a group of teachers in a dance academy/school.

A total of 733 professional ballroom dancers were contacted in Brazil (Figure 1). Contact was established with the dancers and dance schools by telephone, e-mail and/or social networks. Firstly, contact was made with the directors and choreographers of dance schools and companies. With their authorization, the questionnaire was sent to each dancer identified in the group. More than one attempt was made to contact dancers who did not respond to the first message inviting them to take part in the study. Of the total, 366 answered the questionnaire completely, and 320 dancers who met the inclusion criteria were selected, coming from the North and Northeast (20 dancers), Center-West (24 dancers), South (106 dancers) and Southeast (170 dancers) regions of Brazil.

The dancers were invited to take part in the study voluntarily, and after communicating the objectives and procedures and accepting to take part, they signed a Free and Clarified Term of Consent (FCTC) online. With respect to the online acceptance, the dancer had two options concerning to the study: 'accept to take part' or 'not accept to take part'. The dancer could also opt to receive the results of the survey by filling in his/her data.

The data was collected in the period from November 2016 to June 2017 by an online questionnaire in GoogleDocs, in which the spreadsheets were administered by the principal researcher of the study. The link was sent to the director of the company and/or school, and if authorized by him/her, was then sent directly to each dancer. Thus a self-applied questionnaire was used for the collection, divided into two blocks:

a. General information: age, sex, practice of physical activity - relating to weekly practice (times per week) and type of activity (statistically classified into body techniques, resistance exercise, sports in general and others, excluding ballroom dancing and other dances) questions about physical activity elaborated by the authors of this study) - time of systematized practice of ballroom dancing, company or dance school employee, practice of other types of dancing in addition to ballroom dancing, and the anthropometric variables of which the body mass and height, used to calculate the BMI, were self-referred by the dancers due to the collection being online. The BMI was calculated by dividing the body mass in kilos by the height squared in meters. The status was classified according to the cutoff points established by the World Health Organization $^{12}$ which classifies individuals with a BMI below $18.5 \mathrm{~kg} / \mathrm{m}^{2}$ as being underweight, those between 18.5 and $24.9 \mathrm{~kg} / \mathrm{m}^{2}$ as being ideal (eutrophic), between 25 and $29.9 \mathrm{~kg} / \mathrm{m}^{2}$ as being overweight, and above or equal to $30 \mathrm{~kg} / \mathrm{m}^{2}$ as obese. For statistical purposes, 


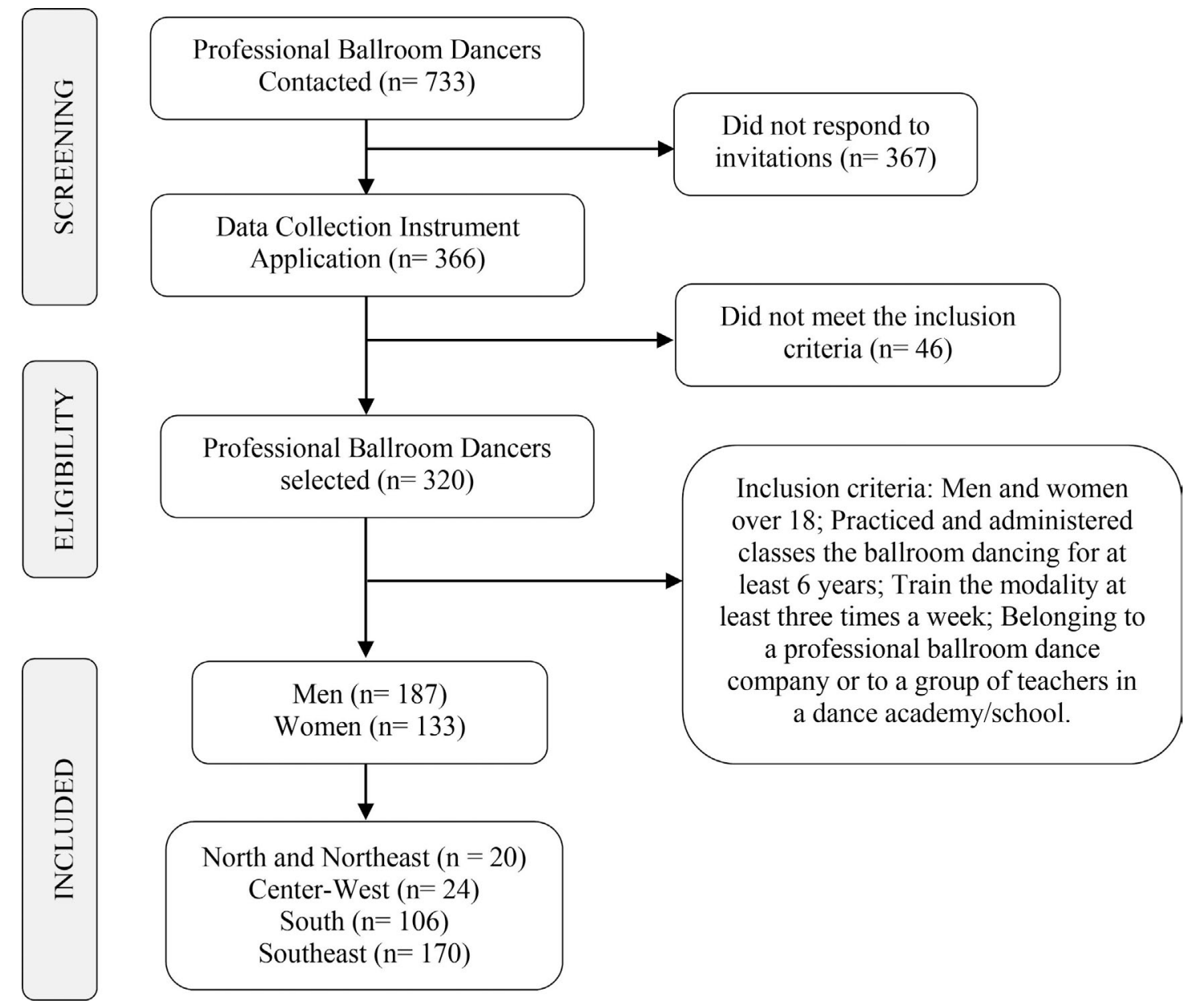

Figure 1 - Flowchart of participants.

due to the small numbers of dancers in the underweight and obese categories, the categories were regrouped as normal weight (underweight + ideal) and overweight (overweight + obese).

b. Injuries: these were evaluated using a self-administered questionnaire adapted for professional Brazilian dancers by Lima, Silva \& Barreto ${ }^{13}$. The Questionnaire for the Identification of Injuries in Dancers of different modalities consisted of 14 objective, multiple-choice questions covering the presence of injuries, the anatomical location, the structure affected, the frequency (the one, two or three most important ones during the dance career), perception of risk factors, the type and/ or practice which caused the injury and the post-injury actions. For the data analysis reported in this article, only the responses referring to the first injury cited by the dancer were considered, that is, the most relevant one of his/her professional careers.

The statistical analysis was carried out using the SPSS-IBM packet, version 20.0. A descriptive analysis was carried out first to determine the data distribution of each variable, followed by an inferential analysis. Data normality was assessed by the Kolmogorov-Smirnov test. In order to analyze the relationship of the presence of injuries with the independent variables, the crude and fitted odds ratios (OR) were estimated by Binary Logistic Regression, with their respective 95\% CI (Confidence intervals). For the data analysis, the sample was divided into two groups, men and women, due to the different associations of the type of injury between the sexes. The value of $p \leq 0.20$ was determined as the criterion to remain in the fitted analysis. The level of significance was $5 \%$.

\section{Results}

A total of 320 professional ballroom dancers took part in this study, with a mean age of $31.48 \pm 8.63$ years, $58.4 \%$ male and $41.6 \%$ female. Of those investigated, $50.6 \%$ had between six and 10 years of contact with ballroom dancing and $53.8 \%$ maintained a periodic practice of the modality of between five and seven times a week. In addition, $48.8 \%$ practiced some other type of dance and $72.8 \%$ carried out other physical activities in addition to dance, resistance exercise is the most practiced (49.8\%) 
Injuries in Professional Dancers

(data not presented). With respect to the occurrence of injuries, $64.1 \%$ of the dancers reported having suffered some kind of injury during their professional career. Of these, $41.3 \%$ cited just one injury, $17.8 \%$ up to two injuries and $8.1 \%$ up to 3 injuries due to the practice, of which $60.3 \%$ referred to the right-hand side of the body (data not presented).

Table 1 shows the characterization of the injuries suffered by the dancers. It can be seen that for women, the anatomical location most frequently affected were the lower limbs $(31.1 \%)$, whereas for men it was the knee (28.7\%). Musculoskeletal injuries were the most reported by both sexes $(80.0 \%)$, especially osteoarticular injuries $(52.4 \%)$. With respect to the activities which caused the injuries, biomechanical stress due to continuous practice was the reason most cited by both sexes $(40.1 \%)$, and during rehearsals were the moments when they most occurred $(33.7 \%)$. Concerning the incidence, the majority of the injuries were referred to as new $(48.8 \%)$ and of moderate intensity $(56.1 \%)$, by both men and women. Although $73.2 \%$ of the women felt their performance was directly affected by the injury, $53.0 \%$ of the men opted to continue their activities normally, whereas $52.2 \%$ of the women decided to stop their dancing activities due to the injury suffered. Of the dancers who opted to stop their dancing activities, $66.4 \%$ remained on leave for up to 1 month, and currently, 59.6\% consider themselves to have recovered.

Table 2 shows the odds ratio and prevalence of associated factors for the presence of injuries in professional male dancers. It can be seen that the chances of an overweight dancer having injuries was 1.729 times greater than that of a dancer of normal weight $(p=0.093)$. When the men reported the practice of ballroom dancing for more than 11 years, the chances of having injuries were 1.707 times greater than for those who had only practiced for 6 to 10 years $(p=0.099)$. With respect to being employed by a dance company, those who reported this employment had a 2.321 times greater chance of having injuries, and those who were on leave from their companies had a 3.509 times greater chance of having injuries, when compared to those who had no employment $(p=0.019)$. In addition, those who practiced some other physical activity besides the systematic practice of ballroom dancing had a 2.190 times greater chance of having injuries as compared to those who did not practice any other physical activity $(\mathrm{p}=0.023)$.

When considering the odds ratio and prevalence of associated factors for the presence of injury in female dancers (Table 3), it can be seen that the chance of overweight dancers presenting injuries was 0.343 times smaller when compared to those of normal weight $(p=0.026)$. On the other hand, women who practiced other dance modalities besides ballroom dancing had a 1.928 times greater chance of having injuries than those who dedicated themselves exclusively to ballroom dancing $(\mathrm{p}=0.105)$.
Table 1 - Characterization of the injuries to professional ballroom dancers according to sex - Brazil, 2015-2016 $(\mathrm{n}=205)$.

\begin{tabular}{|c|c|c|c|}
\hline Variables & $\begin{array}{c}\text { Total } \\
(\%)\end{array}$ & $\begin{array}{c}\text { Men } \mathbf{n}=115 \\
(\%)\end{array}$ & $\begin{array}{c}\text { Women } \\
\mathbf{n}=90(\%)\end{array}$ \\
\hline \multicolumn{4}{|l|}{ Anatomical location } \\
\hline Knee & 28.3 & $33(28.7)$ & $25(27.8)$ \\
\hline LLLL (leg/calf/ankle/foot) & 23.4 & $21(17.4)$ & $28(31.1)$ \\
\hline Shoulder & 15.6 & $23(20.0)$ & $9(10.0)$ \\
\hline Back (cervical/thoracic/lumbar) & 15.1 & $20(18.4)$ & $9(10.0)$ \\
\hline Hips & 11.2 & $8(7.0)$ & $15(16.7)$ \\
\hline UULL (arm/forearm/wrist) & 6.8 & $10(8.7)$ & $4(4.4)$ \\
\hline \multicolumn{4}{|l|}{ Type of injury } \\
\hline Musculoskeletal injuries & 80.0 & $91(79.1)$ & $73(81.1)$ \\
\hline Bone fractures & 20.0 & $24(20.9)$ & $-17(18.9)$ \\
\hline \multicolumn{4}{|l|}{ Activity that caused the injury } \\
\hline $\begin{array}{l}\text { Biomechanical stress due to con- } \\
\text { tinuous practice }\end{array}$ & 40.1 & $30(34.1)$ & $37(46.8)$ \\
\hline Jump/wrong landing on ground & 21.0 & $14(15.9)$ & $21(26.6)$ \\
\hline Twisting/change of direction & 16.8 & $21(23.9)$ & $7(8.9)$ \\
\hline Incorrect execution of movement & 13.8 & $10(11.4)$ & $13(16.5)$ \\
\hline $\begin{array}{l}\text { Bumped into other person/ lift- } \\
\text { ing }\end{array}$ & 8.4 & $13(14.8)$ & $1(1.3)$ \\
\hline \multicolumn{4}{|l|}{ Moment when it occurred } \\
\hline Rehearsal & 33.7 & $38(33.0)$ & $31(34.0)$ \\
\hline Class & 23.9 & $24(20.9)$ & $25(27.8)$ \\
\hline Routine training & 20.0 & $23(20.0)$ & $18(20.0)$ \\
\hline Practicing exercises & 13.2 & $18(15.7)$ & $9(10.0)$ \\
\hline Spectacle & 9.3 & $12(10.4)$ & $7(7.8)$ \\
\hline \multicolumn{4}{|l|}{ Incidence of injury } \\
\hline New injury & 48.8 & $62(53.9)$ & $38(42.2)$ \\
\hline Chronic injury & 33.7 & $33(28.7)$ & $36(40.0)$ \\
\hline Re-incidence ( $2^{\text {nd }}$ time $)$ & 11.2 & $11(9.6)$ & $12(13.3)$ \\
\hline Complication of previous injury & 6.3 & $9(7.8)$ & $4(4.4)$ \\
\hline \multicolumn{4}{|l|}{ Intensity of injury } \\
\hline Moderate & 56.1 & $68(59.1)$ & $47(52.2)$ \\
\hline Severe & 22.4 & $21(18.3)$ & $25(27.8)$ \\
\hline Mild & 21.5 & $26(22.6)$ & $18(20.0)$ \\
\hline \multicolumn{4}{|l|}{ Performance affected or not } \\
\hline Yes & 73.2 & $82(71.3)$ & $68(75.6)$ \\
\hline No & 26.8 & $33(28.7)$ & $22(24.4)$ \\
\hline \multicolumn{4}{|l|}{ Sequence of injury } \\
\hline Continued activities & 50.7 & $61(53.0)$ & $43(47.8)$ \\
\hline Stopped activities & 49.3 & $54(47.0)$ & $47(52.2)$ \\
\hline \multicolumn{4}{|l|}{ Stopped for how long? } \\
\hline Up to 1 month & 66.4 & $41(67.2)$ & $34(65.4)$ \\
\hline Up to 3 months & 17.7 & $10(16.4)$ & $10(19.2)$ \\
\hline More than 4 months & 15.9 & $10(16.4)$ & $8(15.4)$ \\
\hline \multicolumn{4}{|l|}{$\begin{array}{l}\text { Do you feel completely recov- } \\
\text { ered? }\end{array}$} \\
\hline Yes & 59.6 & $68(59.6)$ & $53(59.6)$ \\
\hline No & 40.4 & $46(40.4)$ & $36(40.4)$ \\
\hline
\end{tabular}

Source: produced by author, 2016. The table only refers to injured dancers within the sample.

Abbreviations: \%: frequency; $\mathrm{n}=$ sample number; UULL: upper limbs; LLLL: lower limbs. 
Table 2 - Crude and fitted odds ratio and prevalence of associated factors for the presence of injuries in professional male ballroom dancers, Brazil, 2015$2016(n=115)$.

\begin{tabular}{|c|c|c|c|c|c|}
\hline \multirow[t]{3}{*}{ Variables } & \multirow[t]{3}{*}{ Total $\mathbf{N}^{\mathbf{0}}(\%)$} & \multicolumn{4}{|c|}{ Presence of injury } \\
\hline & & \multicolumn{2}{|c|}{ Crude } & \multicolumn{2}{|c|}{ Fitted } \\
\hline & & OR (CI 95\%) & p-value & OR (CI 95\%) & p-value \\
\hline Weight status & & & 0.105 & & 0.093 \\
\hline Normal weight & $51(44.3)$ & 1 & & 1 & \\
\hline Overweight & $64(55.7)$ & $1.641(0.902 ; 2.985)$ & & $1.729(0.913 ; 3.273)$ & \\
\hline Practice time & & & 0.050 & & 0.099 \\
\hline 6 to 10 years & $45(39.1)$ & 1 & & 1 & \\
\hline Over 11 years & $70(60.9)$ & $1.817(1.000 ; 3.302)$ & & $1.707(0.903 ; 3.227)$ & \\
\hline Practice of other dances & & & 0.228 & & \\
\hline Yes & $55(46.8)$ & $1.455(0.791 ; 2.676)$ & & - & \\
\hline No & $60(53.2)$ & 1 & & - & \\
\hline Give classes & & & 0.914 & & \\
\hline Yes & 107(93.0) & $1.108(0.180 ; 6.806)$ & & - & \\
\hline Not currently & $5(4.3)$ & $0.833(0.090 ; 7.675)$ & & - & \\
\hline Never did & $3(2.6)$ & 1 & & - & \\
\hline Company contract & & & 0.017 & & 0.019 \\
\hline Yes & $65(56.5)$ & $2.124(1.092 ; 4.131)$ & & $2.321(1.150 ; 4.685)$ & \\
\hline On leave & $23(20.0)$ & $3.651(1.352 ; 9.855)$ & & $3.509(1.242 ; 9.914)$ & \\
\hline No & $27(23.5)$ & 1 & & 1 & \\
\hline Weekly practice & & & 0.425 & & \\
\hline Up to 4 times & $50(43.5)$ & 1 & & - & \\
\hline From 5 to 7 times & $65(56.5)$ & $0.782(0.428 ; 1.430)$ & & - & \\
\hline Practice of PA & & & 0.008 & & 0.023 \\
\hline Yes & $89(77.4)$ & $2.390(1.256 ; 4.550)$ & & $2.190(1.115 ; 4.299)$ & \\
\hline No & $26(22.6)$ & 1 & & 1 & \\
\hline
\end{tabular}

Source: produced by author, 2016. The table only refers to injured dancers within the sample.

Abbreviations: OR - odds ratio; CI - confidence interval; PA - physical activity.

Binary Logistic regression - data fitted according to weight status, practice time, company contract and practice of physical activity

\section{Discussion}

This study aimed to analyze the prevalence, characteristics and possible factors associated with injuries in professional ballroom dancers in Brazil, considering any possible differences between the sexes. Thus, it was identified that musculoskeletal injuries were the most prevalent in dancers of both sexes, and the dancers reported having suffered at least one injury in their professional careers. Of the factors associated with injuries in the male dancers, one must highlight the weight status, practice time, company employment and the practice of other physical activities, whereas in the female dancers the weight status and practice of other dance modalities were the main factors associated.

The present study identified the knees, shoulders and back, specifically the cervical, thoracic and lumbar regions as the anatomical regions most affected in male professional ballroom dancers. Similar results were found by Dore \& Guerra ${ }^{14}$ on investigating the symptomatology pain in professional ballet dancers, identifying a general prevalence of moderate to intense pain, in the lumbar region and knees. These results corroborated with the previous study ${ }^{15}$, who analyzed the musculoskeletal injury profile in professional, pre-professional and amateur classical ballet dancers, and found a greater prevalence of injuries in the lower limbs, specifically in the ankle, foot and lumbar regions, followed by the cervical back region.

Although the shoulders appeared in the present study as a region frequently affected in dancers, no studies were found in the literature that investigated this part of the human body in professional dancers of different modalities. Nevertheless, professional dancers are considered to be elite athletes, corroborating with the study of Carvalho et al. ${ }^{16}$, which emphasized the fact that complaints about painful shoulders are common in athletes who work with pitching, this type of injury is favored by trauma, repeated movements, instabilities and degenerative alterations related to age, and one can make parallels with professional ballroom dancing in which couples constantly train aerial steps which included lifting the partner, twisting and pitching ${ }^{16}$. These steps, commonly known as "lifting", generally consist of movements that pitch the lady 
Table 3 - Crude and fitted chance ratios and prevalence of associated factors for the presence of injuries in professional female ballroom dancers, Brazil, 2015-2016 $(n=90)$.

\begin{tabular}{|c|c|c|c|c|c|}
\hline \multirow[t]{3}{*}{ Variables } & \multirow[t]{3}{*}{ Total $N^{\circ}(\%)$} & \multicolumn{4}{|c|}{ Presence of injury } \\
\hline & & \multicolumn{2}{|c|}{ Crude } & \multicolumn{2}{|c|}{ Fitted } \\
\hline & & OR (CI 95\%) & p-value & OR (CI 95\%) & p-value \\
\hline Weight status & & & 0.025 & & 0.026 \\
\hline Normal weight & $79(88.0)$ & 1 & & 1 & \\
\hline Overweight & $11(12.0)$ & $0.347(0.137 ; 0.876)$ & & $0.343(0.133 ; 0.882)$ & \\
\hline Practice time & & & 0.805 & & \\
\hline 6 to 10 years & $52(57.8)$ & 1 & & - & \\
\hline Over 11 years & $38(42.2)$ & $1.110(0.518 ; 2.333)$ & & - & \\
\hline Practice of other dances & & & 0.091 & & 0.105 \\
\hline Yes & $54(60.0)$ & $1.924(0.902 ; 4.104)$ & & $1.928(0.871 ; 4.268)$ & \\
\hline No & $36(40.0)$ & 1 & & 1 & \\
\hline Give classes & & & 0.593 & & \\
\hline Yes & $70(77.8)$ & $1.810(0.577 ; 5.681)$ & & - & \\
\hline Not currently & $14(15.6)$ & $1.750(0.420 ; 7.288)$ & & - & \\
\hline Never did & $6(6.7)$ & 1 & & - & \\
\hline Company contract & & & 0.237 & & \\
\hline Yes & $51(56.2)$ & $2.039(0.854 ; 4.868)$ & & - & \\
\hline On leave & $18(20.2)$ & $1.200(0.430 ; 3.351)$ & & - & \\
\hline No & $21(23.6)$ & 1 & & - & \\
\hline Weekly practice & & & 0.828 & & \\
\hline Up to 4 times & $47(52.2)$ & 1 & & - & \\
\hline From 5 to 7 times & $43(47.8)$ & $0.921(0.441 ; 1.925)$ & & - & \\
\hline Practice of PA & & & 0.618 & & \\
\hline Yes & $70(77.8)$ & $1.240(0.532 ; 2.886)$ & & - & \\
\hline No & $20(22.2)$ & 1 & & - & \\
\hline
\end{tabular}

Source: produced by author, 2016. The table only refers to injured dancers within the sample.

Abbreviations: OR - odds ratio; CI - confidence interval; PA - physical activity.

Binary Logistic regression - data fitted according to weight status and practice of other dance modalities.

into the air, catch her back and maintain her in the arms of the gentleman. Specifically, in the case of ballroom dancing, the hypothesis was raised that these movements could contribute to the fact that the shoulders become a susceptible region for the development of injuries in male dancers since it is the gentleman who carries out these aerial steps.

In general, the demands of the training routine of professional male ballroom dancers result from the extenuating repetition of choreographies, sequences, and steps, generally based on falls, jumps, and twists, demanding stretching, flexibility, and balance by using both dynamic and static strength in a search for synchronism and harmony of the couple, combined with an improved technical repertoire ${ }^{17}$. These factors have direct repercussions on joint and postural overloads, explaining why the knees and back are the anatomical regions frequently affected in these populations.

With respect to the type of injury, musculoskeletal injuries were the most frequent in the professional ballroom dancing sample, as also reported in the current lit- erature, confirming the prevalence of musculoskeletal injuries in classical ballet ${ }^{15,18}$; modern ballet ${ }^{19,20}$ and breakdance dancers ${ }^{21,22}$. In the context of professional sport, musculoskeletal injuries are also the most prevalent and can reach an index of $65 \%$ in international competitions $^{9,23}$.

There are many causes of this type of injury, such as the elevated time dedicated to the modality, the extenuating training load and the lack of structure offered. These are combined with the physical, technical and tactical demands, indicated as possible risk factors for the development of this type of injury, both in dancing and high yield sports ${ }^{1,20}$. The present study also made it possible to identify osteoarticular injuries as the most important among the musculoskeletal injuries, in a sex-independent manner, in agreement with a hybrid cross-sectional study concerning dancing injuries. The authors concluded that osteoarticular diseases could be associated with the age of the dancers, the time they have practiced the determined modality of dancing and also with the use of pointed shoes $^{24}$, an association that can also be made with ball- 
room dancing. Considering that the time of practice for male dancers and the practice of other dance modalities for female dancers, demonstrated greater odds ratios for the occurrence of injuries, it should be mentioned that female ballroom dancers, as also those of classical ballet, use clothing that favors the development of injury, specifically high-heeled sandals, which usually have restricted bases and favor postural instability ${ }^{5}$.

Another risk factor that demonstrated a greater chance ratio for the occurrence of injuries in the present study was the weight status, independent of sex. Some studies carried out in the area of professional dancing, generally with classical ballet, portrayed male dancers as eutrophic individuals and commonly within the range of normality ${ }^{6}$. Nevertheless, the sample investigated identified professional dancers, both male and female, who were overweight. For the present study, the proposed interpretation was that the ballroom dancing modality, even in the professional context, permits and accepts different existing body standards for both sexes on a much larger scale, different from the case of classical ballet. Another factor was that dancing classes are an intermittent physical activity, reaching aerobic intensities of low and moderate levels ${ }^{25}$.

Regarding the professional male dancers analyzed in the present study, the results showed that overweight was associated with an increased chance of having injuries. This could have occurred due to the fact that overweight has a direct effect on the overload on the joints during the execution of the movements ${ }^{26}$. On the other hand, in female dancers overweight was associated with a decreased chance of having injuries, which leads one to reflect on the results since they were different from those of the male dancers, leading to the hypothesis that the overweight female dancers were probably less exposed to movements that favored the development of injuries, specifically jumps and aerial steps or "lifts".

Also related to the differences between the sexes identified in the fitted logistic regression analysis, male dancers who had practiced ballroom dancing for more than 11 years, were employed by a company and practiced some other kind of physical activity, showed greater chances of having injuries, whereas, in the case of the female dancers, the variable of practicing other dance modalities showed an increased chance of having injuries. Thus, it was confirmed that for both sexes, the excess of training sessions/ rehearsals and extenuated continuous practice, be it in other dance modalities or other complementary physical activities, increased the risk of injuries ${ }^{18}$.

The search of these dancers for activities that complemented their training routine was evidence of their professional dedication to the modality of dancing, just as high yield sport requires the development of advanced technical knowledge and the improvement of specific abilities at high demand levels ${ }^{18}$. This fact has been reported in the li- terature as a potential cause of the development of injuries in the different dance modalities ${ }^{1,2,5,6}$.From the results obtained in the present study, it was possible to verify that the expected hypothesis was confirmed in parts since the presence of lesion was found in more than half of the sample. However, although individuals of both sexes presented some type of lesion injury, there was no gender disparity.

\section{Conclusion}

This research was highly relevant since it was the first destined to investigating the epidemiology, prevalence and possible factors associated with injuries in professional ballroom dancers in Brazil. The non-use of direct measurements to evaluate the injuries, since the research was done online, was considered a limiting factor of this study. In addition, since this was a cross-sectional study, the causes and effects could not be found. However, it must be mentioned that the fact that the data were collected online using indirect measurements allowed the research to be nationwide, with the objective of accessing a larger number of professional dancers, and it did not depend on any type of financial aid.

Thus, the authors suggest that more studies be carried out with this population, giving attention to the possible difference between sexes, practice time and the various rhythms in the ballroom dancing modality. In addition, the elaboration of an instrument that specifically evaluates the injuries in professional dancers of the different dance modalities is recommended, with a focus on the incidence, seriousness, principal regions affected and etiology of injuries. This would foment both preventative actions as well as rehabilitation processes for the injuries that commonly occur amongst these individuals, favoring a healthy and safe career for all those involved in the professional practice of dancing.

\section{Acknowlegdments}

The authors thank the professional ballroom dancers, schools and dance companies who volunteered to participate in the research; the Laboratory of Research in Leisure and Physical Activity of the State University of Santa Catarina, Florianopolis, SC, Brazil; and CAPES, for their support in granting the masters and doctorate scholarships to the researchers in question.

\section{References}

1. Kotler DH, Lynch M, Cushman D, HU J, Garner J. Dancers' Perceived and Actual Knowledge of Anatomy. J Dance Med Sci. 2017;21(2):76-81. DOI: 10.12678/1089-313X.21.2.76.

2. Mayes S, Ferris AR, Smith P, Garnham A, Cook J. Professional ballet dancers have a similar prevalence of articular cartilage defects compared to age- and sex-matched nondancing athletes. Clin Rheumatol. 2016;35(12):3037-3043. 
3. Cardoso AA, Reis NM, Marinho AP, Boing L, Guimarães ACDA. (2017). Study of Body Image in Professional Dancers: a Systematic Review. Rev Bras Med Esporte. 2017;23 (4):335-340. DOI: 10.1590/1517-869220172304162818.

4. Stevens-Ratchford RG. Ballroom Dance: Linking Serious Leisure to Successful Aging. Int J Aging Hum Dev. 2016; 0:1-19. DOI: 10.1177/0091415016652405.

5. Castelani RA, Oliveira TF de, Faquin BS, Dascal JB, Marques I, Okazaki VHA. Análise do equilíbrio dinâmico em praticantes de balé clássico, de dança de salão e de não praticantes de dança. Rev. educ. fis. UEM. 2014;25(4):597607. DOI: 10.4025/reveducfis.v25i4.22951.

6. Domene PA, Stanley M, Skamagki G. Injury surveillance of nonprofessional salsa dance. J Phys Act Health. 2018:1-7. DOI: 10.1123/jpah.2017-0498.

7. Hopper LS, Allen N, Wyon M, Alderson JA, Elliott BC, Ackland TR. Dance floor mechanical properties and dancer injuries in a touring professional ballet company. J Sci Med Sport. 2014,17(1):29-33. DOI: $\quad$ 10.1016/j. jsams.2013.04.013.

8. Mcgalashan AJ, Finch CF. The extent to which behavioural and social sciences theories and models are used in sport injury prevention research. Sports Medicine. 2010; 40 (10):841-58. DOI: 10.2165/11534960-000000000-00000.

9. Saragiotto BT, Di Pierro C, Lopes AD. Risk factors and injury prevention in elite athletes: a descriptive study of the opinions of physical therapists, doctors and trainers. Braz J Phys Ther. 2014;18(2):137-143. DOI: 10.1590/S141335552012005000147.

10. Hincapie CA, Morton EJ, Cassidy JD. Musculoskeletal injuries and pain in dancers: a systematic review. Arch Phys Med Rehabil. 2008;89(9):1819-1829. DOI: 10.1016/j. apmr.2008.02.020.

11. Cardoso AA, Reis NM, Marinho APR, Vieira MDCS, Boing L, Guimarães ACDA. Injuries in professional dancers: a systematic review. Rev Bras Med Esporte, 2017;23(6): 504509. DOI: 10.1590/1517-869220172306170788.

12. WHO. World Health Organization. The International Classification of adult underweight, overweight and obesity according to BMI, 2004. Disponível em: http://apps.who. int/bmi/index.jsp?introPage=intro_3.html. Acesso em: 05 de dezembro de 2016.

13. Lima KA, Silva PHB, Barreto RR. Características das lesões em bailarinos e sua relação com a qualidade de vida. Revista Movimenta. 2014;7(1):645-659.

14. Dore BF, Guerra RO. Sintomatologia dolorosa e fatores associados em bailarinos profissionais. Rev Bras Med Esporte. 2007;13(2):77-80.

15. Smith TO, Davies L, de Medici A, Hakim A, Haddad F, Macgregor A.Prevalence and profile of musculoskeletal injuries in ballet dancers: A systematic review and metaanalysis.Phys Ther Sport. 2016;19:50-6. DOI: 10.1016/j. ptsp.2015.12.007.

16. Carvalho CD, Cohen C, Belangero PS, Figueiredo EA, Monteiro GC, Pochini AC, Andreoli CV, Ejnisman B. Lesão parcial do manguito rotador no atleta - bursal ou articular? Revista Brasileira de Ortopedia 2015;50(4):416-421. DOI: 10.1016/j.rbo.2014.07.002.
17. Farencena EZP, Júnior DM, Gross DGL, Rodrigues ESR. Dança de salão e sua contribuição para melhoria da saúde e qualidade de vida. Ama Science \& Health. 2016;4(1):10-16.

18. Costa MSS. Characteristics and prevalence of musculoskeletal injury in professional and non-professional ballet dancers. Braz J Phys Ther. 2016;20(2):166-175. DOI: 10.1590/ bjpt-rbf.2014.0142.

19. Bronner S, Wood L. Impact of touring, performance schedule, and definitions on 1-year injury rates in a modern dance company. J Sports Sci. 2016:1-12. DOI: 10.1080/ 02640414.2016.1255772.

20. Jacobs CL, Cassidy JD, Côté P, Boyle E, Ramel E, Ammendolia C, Hartvigsen J, Schwartz I. Musculoskeletal Injury in Professional Dancers: Prevalence and Associated Factors: An International Cross-Sectional Study. Clin J Sport Med. 2016. DOI: 10.1097/JSM.0000000000000314.

21. Joka T, Clarke ND, Cohen DD, Delextrat A. Etiology of musculoskeletal injuries in amateur breakdancers. J Sports Med Phy Fitness 2015;55(2):1-2.

22. Kauther MD, Wedemeyer C, Wegner A, Kauther KM, von Knoch M. Breakdance injuries and overuse syndromes in amateurs and professionals. Am J Sports Med. 2009;37 (4):797-802. DOI: $10.1177 / 0363546508328120$.

23. Engebretsen L, Soligard T, Steffen K, Alonso JM, Aubry M, Budgett R, Dvorak J, Jegathesan M, Meeuwisse WH, Mountjoy M, Palmer-Green D, Vanhegan I, Renström PA. Sports injuries and illnesses during the London Summer Olympic Games 2012. Br J Sports Med. 2013;47(7):407414. DOI: $10.1136 /$ bjsports-2013-092380.

24. Grego LG, Monteiro HL, Padovani CR, Gonçalves A. Lesões na dança: estudo transversal híbrido em academias da cidade de Bauru-SP. Rev Bras Med Esporte. 1999;5 (2):47-54.

25. Rodrigues-Krause J, Cunha GS dos, Alberton CL, Follmer B, Krause M, Reischak-Oliveira A. Oxygen consumption and heart rate responses to isolated ballet exercise sets. J Dance Med Sci. 2014;18(3): 99-105.

26. Jiang L, Xie X, Wang Y, Wang Y, Lu Y, Tian T, Chu M, Shen Y. Body mass index and hand osteoarthritis susceptibility: an updated meta-analysis. Int J Rheum Dis. 2016;19 (12):1244-1254. DOI: 10.1111/1756-185X.12895.

\section{Corresponding author}

Allana Alexandre Cardoso. Sports Pedagogy Laboratory / Sports Center. Campus Rector João David Ferreira Lima, s/n - Bairro Trindade. 88040-900 Florianópolis, SC,

Brasil.

E-mail: allana.alexandre@gmail.com.

Manuscript received on March 28, 2019

Manuscript accepted on February 11, 2020

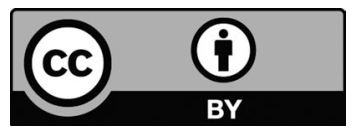

Motriz. The Journal of Physical Education. UNESP. Rio Claro, SP, Brazil - eISSN: 1980-6574 - under a license Creative Commons - Version 4.0 